\title{
Modeling and Characteristic Parameters Analysis of a Trough Concentrating Photovoltaic/Thermal System with GaAs and Super Cell Arrays
}

\author{
Xu Ji, ${ }^{1}$ Ming Li, ${ }^{1}$ Weidong Lin, ${ }^{1}$ Wenbo Wang, ${ }^{2}$ Liuling Wang, ${ }^{2}$ and Xi Luo ${ }^{1}$ \\ ${ }^{1}$ Solar Energy Research Institute, Yunnan Normal University, Kunming 650092, China \\ ${ }^{2}$ School of Physics and Electronic Information, Yunnan Normal University, Kunming 650092, China \\ Correspondence should be addressed to Ming Li, liming@ynnu.edu.cn
}

Received 5 April 2012; Revised 4 July 2012; Accepted 11 July 2012

Academic Editor: G. N. Tiwari

Copyright (C) $2012 \mathrm{Xu}$ Ji et al. This is an open access article distributed under the Creative Commons Attribution License, which permits unrestricted use, distribution, and reproduction in any medium, provided the original work is properly cited.

The paper established the one-dimension steady models of a trough concentrating photovoltaic/thermal system with a super cell array and a GaAs cell array, respectively, and verified the models by experiments. The gaps between calculation results and experimental results were less than $5 \%$. Utilizing the models, the paper analyzed the influences of the characteristic parameters on the performances of the TCPV/T system with a super cell array and a GaAs cell array, respectively. The reflectivity of the parabolic mirror in the TCPV/T system was an important factor to determine the utilizing efficiency of solar energy. The performances of the TCPV/T system can be optimized by improving the mirror reflectivity and the thermal solar radiation absorptivity of the lighting plate and pursuing a suitable focal line with uniform light intensity distribution. All these works will benefit to the utilization of the trough concentrating system and the combined heat/power supply.

\section{Introduction}

The solar concentrating photovoltaic/thermal (CPV/T) system combines the solar cells to the low-cost concentrating collector. The solar energy flux intensity is increased by concentration and tracking sun to improve the output power of solar cells, and meanwhile the forced-circulated cooling water is utilized to ensure photovoltaic cells working normally in concentrating irradiance. The electrical power and the thermal energy are obtained simultaneously from the system. The replacement of the expensive solar cells by the trough parabolic mirrors would result into the reduction of the cost of PV power generation. The combined CPV/T system improves the comprehensive utilization of solar energy.

In 2004, the Renewable Research Institute of Australia National University performed a detailed study on a trough concentrating photovoltaic/thermal (TCPV/T) system. The efficiency of the solar cell array reached $22 \%$, and the cost of electricity generation was reduced by $40 \%$ compared with the traditional PV system [1-3]. Mittelman et al. [4] investigated the performances and cost of a CPV/T system with single-effect absorption cooling in detail. Kribus et al. [5] presented the evaluation and design approach on a miniature concentrating PV (MCPV) system and analyzed the heat transport subsystem, the electrical and thermal performances, the manufacturing cost, and the resulting cost of energy. Tyagi et al. [6] evaluated the exergetic performance of a concentrating solar collector and studied the related parameters based on hourly solar radiation. Shanghai Jiao Tong University also investigated a CPV/T system using Fresnel lens in China, established the one-dimensional steady heat transfer model, and calculated the thermal, electrical, and exergy efficiency [7]. Southeast University of China also developed a one-dimensional steady heat transfer model for a CPVT system with fins and analyzed the effects of air mass flow rate, incident solar intensity, and wind velocity on air temperature and efficiency of air collector [8].

Our research group began to investigate the TCPV/T system in 2005. The performances of some solar cell arrays in our TCPV/T system and of the TCPV/T system with flat-plate PV module were reported in [9-12]. Based on 
the previous works, this paper focuses on the establishment of mathematical models of the TCPV/T system with a super cell array and a GaAs cell array, models validation by experiments, and utilizing the models to analyze the influences of the characteristic parameters on the performances of the system. Some theoretic calculation and some experiments were performed in the work, and the corresponding results were presented. All these works are helpful to the further study on the trough concentrating system.

\section{Working Principle of the TCPV/T System}

Figure 1 shows the configuration of the TCPV/T system. It consists of the parabolic trough concentrator, the receiver, the sun tracking system, the electrical power output system, and the system. The solar cell arrays are pasted on the lighting plate of the receiver with thermally conductive tape, and generate electricity when the sunlight is concentrated on them. With increase of the temperature of the solar cells arrays, the electrical performance of the solar cells arrays will deteriorate. So the forced-circulated cooling water flowing in the inner cavity of the receiver is necessary to reduce the temperature of the solar cells arrays. The heated water is guided and stored in water tank for use. In order to minimize the thermal loss, the inner cavity is encased using the thermal insulation material. The solar energy collected by the system will be converted to electric power and thermal energy via the solar cell arrays and the heated cavity. When the system works, the solar concentrator tracks the sun to collect the direct radiation. The system tracks the solar altitude angle by adjusting the push rod in single-axis east-west tracking mode (trough concentrator north-south oriented).

\section{Mathematical Model of the TCPV/T System}

3.1. The Energy Balance Equations of the TCPV/T System. According to the configuration of TCPV/T system on Figure 2(a), the thermal network of the system is shown on Figure 2(b). The thermal network is used to describe energy flow in the TCPV/T system. The one-dimensional heat transfer model of the system is established in this paper. In order to simplify the calculation, it is assumed that

(1) the heat transfer model is a steady-state model;

(2) all of the thermal physical properties and optical parameters of the materials such as the tube, solar cell array, heat sinking tape, plate, and insulation cover are constants;

(3) The heat conductions of different components along the flowing direction are neglected. The energy flowing balance equations of the TCPV/T system are established as follows.

(a) The solar cell array absorbs and converts the solar direct radiant energy, dissipates heat to the surroundings and conducts heat to the

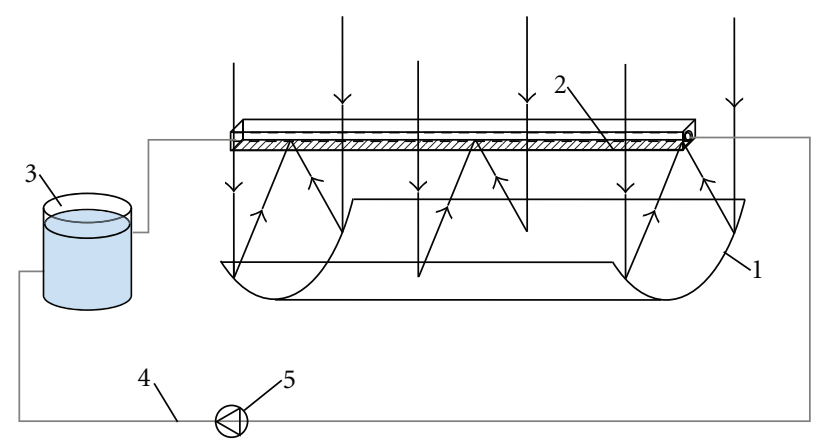

Figure 1: The configuration of the TCPV/T system. (1) Trough concentrator, (2) receiver, (3) storage tank, (4) pipe, and (5) pump.

thermally conductive tape, respectively, simultaneously generates electrical power as follows:

$$
\left(\frac{T_{p}-T_{a}}{R_{\mathrm{cpa}}}+\frac{T_{p}-T_{a}}{R_{\mathrm{rpa}}}\right)+\frac{T_{p}-T_{B}}{R_{\mathrm{kpB}}}=Q_{p}-P_{\max } t,
$$

where $T_{p}$ is the average working temperature of solar cell array, ${ }^{\circ} \mathrm{C} ; T_{a}$ is the ambient temperature, ${ }^{\circ} \mathrm{C}$; $T_{B}$ is the average temperature of the thermally conductive tape, ${ }^{\circ} \mathrm{C} ; R_{\text {cpa }}, R_{\text {rpa }}$ are the convective and radiative heat transfer thermal resistances between solar cell array and the surroundings, respectively, $\Omega ; R_{\mathrm{kpB}}$ is the heat-conductive thermal resistance between solar cell array and the thermally conductive tape, $\Omega ; Q_{P}$ is the solar direct radiant energy on the solar cell array, $\mathrm{kJ} ; P_{\max }$ is the maximum electrical power output, $\mathrm{W} ; t$ is the operating time, s.

(b) The thermally conductive tape absorbs thermal energy from solar cell array and conducts heat to the aluminum-alloy plate as follows:

$$
\frac{T_{B}-T_{p}}{R_{\mathrm{kpB}}}+\frac{T_{B}-T_{\text {plate }}}{R_{\mathrm{kBpl}}}=0,
$$

where $T_{\text {plate }}$ is the temperature of the aluminum-alloy plate, ${ }^{\circ} \mathrm{C} ; R_{\mathrm{kBpl}}$ is the heatconductive thermal resistance between the thermally conductive tape and the aluminum-alloy plate, $\Omega$.

(c) The aluminum-alloy plate absorbs the energy from solar direct radiation and the thermally conductive tape, transfers it to the thermally insulating layer, the conduit, and radiates to the surroundings, respectively

$$
\begin{aligned}
\frac{T_{B}-T_{\text {plate }}}{R_{\mathrm{kBpl}}}+Q_{p 1}= & \frac{T_{\text {plate }}-T_{\text {cover }}}{R_{\text {kplc }}}+\frac{T_{\text {plate }}-T_{t}}{R_{\text {kplt }}} \\
& +\left(\frac{T_{\text {plate }}-T_{a}}{R_{\text {rpla }}}+\frac{T_{\text {plate }}-T_{a}}{R_{\text {cpla }}}\right),
\end{aligned}
$$

where $Q_{P 1}$ is the concentrating solar direct radiant energy on the aluminum alloy plate, $\mathrm{kJ}$; 


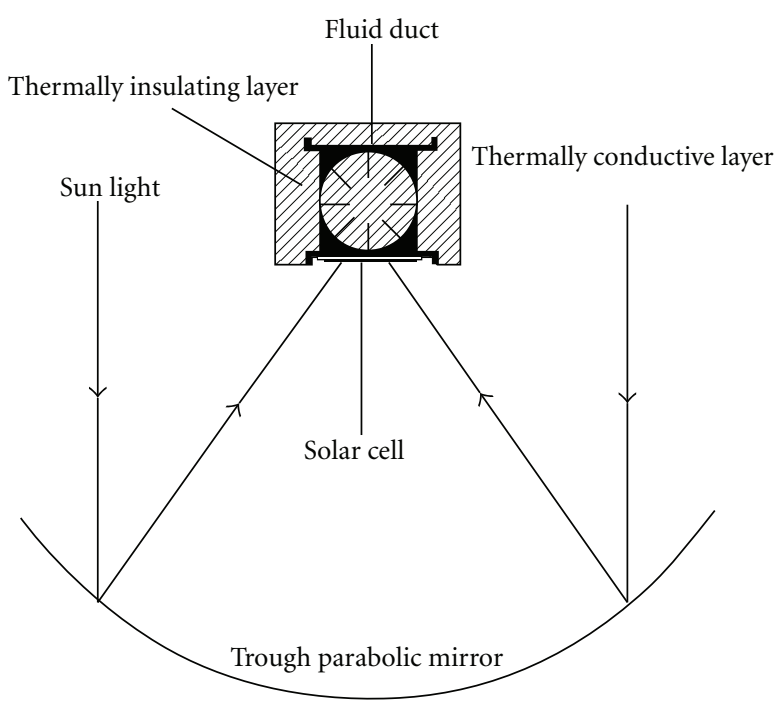

(a)

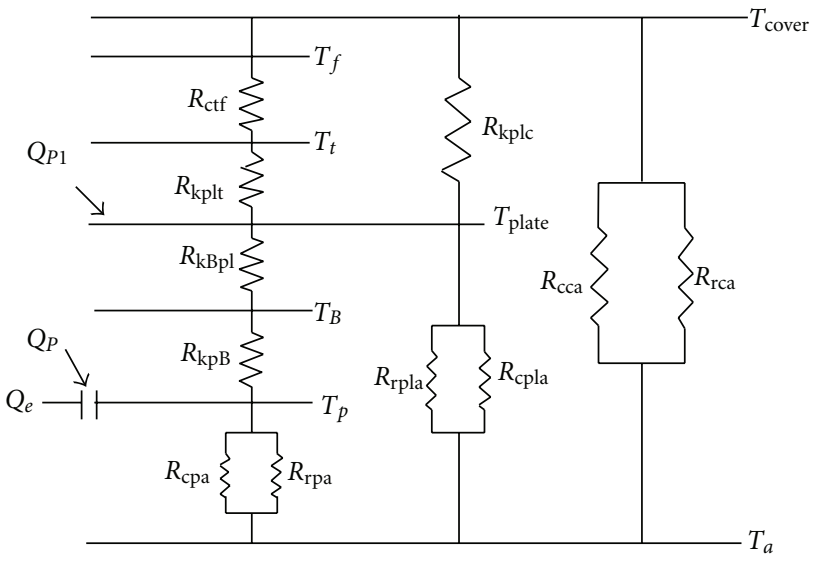

(b)

Figure 2: The thermal network describing the TCPV/T system.

$T_{\text {cover }}$ is the average temperature of the thermally insulating layer, ${ }^{\circ} \mathrm{C} ; T_{t}$ is the temperature of the conduit, ${ }^{\circ} \mathrm{C}$; $R_{\mathrm{kplc}}$ is the heat-conductive thermal resistance between aluminum-alloy plate and the thermally insulating layer, $\Omega$; $R_{\text {kplt }}$ is the heat-conductive thermal resistance between aluminum-alloy plate and the conduit, $\Omega ; R_{\text {rpla }}$ and $R_{\text {cpla }}$ are the convective and radiative heat transfer thermal resistances between the aluminum-alloy plate and the surroundings, respectively, $\Omega$.

(d) The conduit absorbs the thermal energy from the aluminum-alloy plate and transmits to the cooling fluid (water) as follows:

$$
\frac{T_{\text {plate }}-T_{t}}{R_{\text {kplt }}}=m c_{p, f}\left(T_{\text {out }}-T_{\text {in }}\right),
$$

where $m$ is the fluid mass, $\mathrm{kg} ; c_{p, f}$ is the specific heat-capacity, $\mathrm{kJ} /\left(\mathrm{kg} \cdot{ }^{\circ} \mathrm{C}\right) ; T_{\text {out }}$ and $T_{\text {in }}$ are the outlet and inlet fluid temperatures, ${ }^{\circ} \mathrm{C}$.

(e) The relationship between the temperature of the conduit and the inlet and outlet fluid temperatures

$$
\frac{T_{t}-T_{\text {out }}}{T_{t}-T_{\text {in }}}=\exp \left(-\frac{m c_{p, f}}{A_{t} h_{t-f}}\right),
$$

where $A_{t}$ is internal surface area of the conduit, $\mathrm{m}^{2} ; h_{t-f}$ is the convective heat transfer coefficient between the conduit and the fluid, $\mathrm{W} \cdot \mathrm{m}^{-2 \circ} \mathrm{C}^{-1}$.

(f) The thermally insulating layer absorbs the thermal energy from aluminum-alloy plate and radiates heat to the surroundings as follows:

$$
\frac{T_{\text {plate }}-T_{\text {cover }}}{R_{\text {kplc }}}=\left(\frac{T_{\text {cover }}-T_{a}}{R_{\text {rca }}}+\frac{T_{\text {cover }}-T_{a}}{R_{\text {cca }}}\right) \text {, }
$$

$R_{\text {rca }}$ and $R_{\text {cca }}$ are the radiative and convective heat transfer thermal resistance between the thermally insulating layer and the surroundings, respectively, $\Omega$.

In above equations, the output characteristics and the average working temperature of the solar cell array will be obtained by an iterative approach. By assuming the average working temperature of the solar cell array firstly, and adding the electrical power output to calculate the maximum electrical power output, then substitute them into the thermal balance equations. The approach is repeated to get more accurate working temperature and the maximum electrical power output of solar cell array.

3.2. The Electrical Performance of the Solar Cell Array. The current equation of the solar cell is defined as follows:

$$
I=I_{L}-I_{0}\left\{\exp \left[\frac{q\left(V+I R_{s}\right)}{A k T_{p}}\right]-1\right\},
$$

where $I_{L}$ is the photocurrent, $A ; I_{0}$ is the reverse saturation current of the diode, $A ; q$ is the elementary charge, $\mathrm{C}$; $V$ is the load voltage, $V ; R_{s}$ is the series resistance, $\Omega ; A$ is the quality factor of the diode; $k$ is the Boltzmann's constant; $T_{p}$ is the average working temperature of solar cell array, ${ }^{\circ} \mathrm{C}$.

The solar cells are connected in series to constitute the solar cell array. The amount of the solar cell is $n$, the quality factor of the PN junction, the series resistances and the opencircuit voltage of the cell array all increase to $n$ times by those of each solar cell. So the electrical power output of the solar cell array is defined as

$$
P=I\left[\frac{n A k T_{p}}{q} \ln \left(\frac{I_{L}-I}{I_{0}}+1\right)-n I R_{s}\right] .
$$

As for a triple-junction GaAs solar cell array, it is hard to calculate the specific values for each junction 


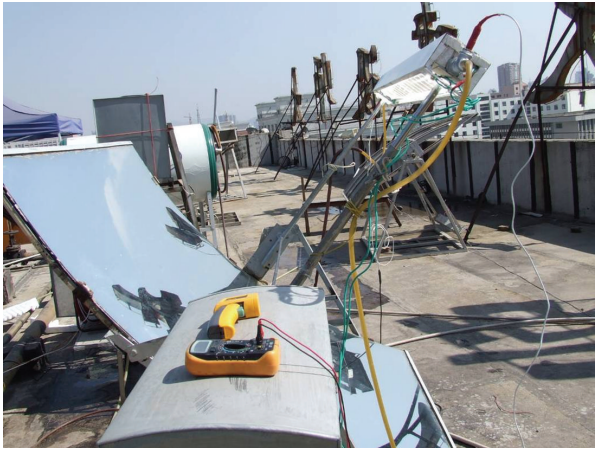

FIgURE 3: The setup of the TCPV/T system.

according to the current (7). But we can get the fitted empirical formula on the basis of experiments. The electrical efficiency corresponding to the maximum electrical power of photovoltaic power generation appears linear with the temperatures of the solar cell array.

$$
\eta_{\mathrm{mp}}=\eta_{\mathrm{mp}, \mathrm{ref}}-\mu_{p, \mathrm{mp}}\left(T_{p}-T_{\mathrm{ref}}\right),
$$

$\eta_{\mathrm{mp}}$ is the electrical efficiency of solar cell array, \%; $\eta_{\mathrm{mp}, \mathrm{ref}}$ is the reference efficiency obtained at reference temperature, $\% ; \mu_{p, \mathrm{mp}}$ is the related coefficient between the electrical efficiency of the solar cell array and the temperature, $\% /{ }^{\circ} \mathrm{C}$; $T_{\text {ref }}$ is the reference temperature $25^{\circ} \mathrm{C}$.

The electrical power output of the triple-junction GaAs solar cell array is defined as

$$
P_{\max }=\frac{\eta_{\mathrm{mp}} Q_{p}}{t}
$$

where $P_{\max }$ is the maximum electrical power output, W; $Q_{P}$ is the solar direct radiant energy on the solar cell array, $\mathrm{kJ} ; t$ is the working time, s.

3.3. The Evaluation of the TCPV/T System. The TCPV/T system can produce electrical power and thermal power simultaneously. Many researchers use the total efficiency $\eta_{0}$, the sum of the electrical efficiency $\eta_{e}$ and the thermal efficiency $\eta_{t}$ to evaluate the performance of the PV/T system [13-15]. The thermal efficiency $\eta_{t}$ and the electrical efficiency $\eta_{e}$ of the TCPV/T system are given by

$$
\begin{gathered}
\eta_{t}=\frac{m c_{p, f}\left(T_{\text {out }}-T_{\text {in }}\right)}{I_{d} A_{m}}, \\
\eta_{e}=\frac{P_{\max }}{I_{d} A_{m}}
\end{gathered}
$$

where $I_{d}$ is the solar direct radiation, $\mathrm{W} / \mathrm{m}^{2} ; A_{m}$ is the effective area of the reflecting mirror, $\mathrm{m}^{2}$.

It is obviously unreasonable to use the total efficiency for evaluating the performance of the TCPV/T system because electrical energy and thermal energy have different energy quality. The reference [14] uses the quantity of economizing primary energy source to evaluate the performance of the PV/T system. Although electrical energy and thermal energy are distinguished to some extent, the difference of the energy quality is still not considered. It is clear that using available energy (exergy) as a performance assessment standard is a reasonable method. The exergy efficiency $\eta_{\text {exergy }}$ of the $\mathrm{TCPV} / \mathrm{T}$ system is shown as follows $[2,14]$ :

$$
\eta_{\text {exergy }}=\frac{\eta_{e} I_{d} A_{m}+m c_{p, f}\left\{\left[h-\left(T_{a}+273.15\right) s\right]_{\text {out }}-\left[h-\left(T_{a}+273.15\right) s\right]_{\text {in }}\right\}}{I_{d} \times\left(1-\left(T_{a}+273.15\right) / 5777\right)},
$$

where $h$ is the specific enthalpy, $\mathrm{kJ} / \mathrm{kg}$; $\mathrm{s}$ is the specific entropy, $\mathrm{kJ} /\left(\mathrm{kg} \cdot{ }^{\circ} \mathrm{C}\right)$.

\section{Validation of the Model by Experiments}

The experimental setup of the TCPV/T system with a geometric concentration ratio of 16.92 is shown in Figure 3. The effective aperture area of the trough parabolic mirror is $1.95 \mathrm{~m}^{2}$, and the mirror reflectivity is 0.69 (tested by ultraviolet spectrophotometer UV3600). The focal length and focal spot width are $1.20 \mathrm{~m}$ and $0.10 \mathrm{~m}$, respectively. The energy flux concentration ratio of the system is 10.27 tested by the laser power instrument MODEL460-1A from EG\&G Gamma Scientific San Diego, CA. The laser power meter can measure the intensities of different wavelength. Averaging the intensities, then divided by the direct solar radiation, we can obtain the energy flux concentration ratio. The length, width, and height of the receiver are $1.50 \mathrm{~m}, 0.12 \mathrm{~m}$, and $0.09 \mathrm{~m}$, respectively. Insider diameter of the conduit is $0.03 \mathrm{~m}$. The related parameters of all materials are shown in Table 1.

The total radiation is measured using the pyranometer TBQ- 2 with an accuracy of $\pm 2 \%$. The direct radiation is measured with the pyrheliometer TBS2-2 with an accuracy of $\pm 2 \%$. The current and voltage of the solar cell arrays are measured with a digital multimeter (Fluke 17B) with an accuracy of $\pm 1.5 \%$. The working temperature of solar cells is measured with a thermometer (Fluke 63) with an accuracy of $\pm 1^{\circ} \mathrm{C}$. The inlet and outlet temperatures of the cooling fluid are measured using the thermocouple temperature probe PT100 with an accuracy of $\pm 0.1^{\circ} \mathrm{C}$. The mass flow is measured by a glass rotameter with an accuracy of $\pm 0.0014 \mathrm{~kg} / \mathrm{s}$. The calculation results based on the theoretical model are verified with the following experimental results.

4.1. The Electrical Performance of the Super Cell Array Based on the TCPV/T System. The super cell array shown in 
TABLe 1: Parameters of structure materials of the system.

\begin{tabular}{|c|c|c|c|c|c|c|c|c|c|c|}
\hline & \multicolumn{5}{|c|}{ Super cell array } & \multicolumn{5}{|c|}{ GaAs cell array } \\
\hline & Cell array & $\begin{array}{c}\text { Thermally } \\
\text { conductive } \\
\text { tape }\end{array}$ & $\begin{array}{l}\text { Aluminum } \\
\text { alloy plate }\end{array}$ & Conduit & $\begin{array}{c}\text { Thermally } \\
\text { insulating } \\
\text { layer }\end{array}$ & Cell array & $\begin{array}{c}\text { Thermally } \\
\text { conductive } \\
\text { tape }\end{array}$ & $\begin{array}{l}\text { Aluminum } \\
\text { alloy plate }\end{array}$ & Conduit & $\begin{array}{c}\text { Thermally } \\
\text { insulating } \\
\text { layer }\end{array}$ \\
\hline $\begin{array}{l}\text { Thermal } \\
\text { conductivity } \\
\text { coefficient } \\
\lambda\left(\mathrm{W} \cdot \mathrm{m}^{2} /{ }^{\circ} \mathrm{C}\right)\end{array}$ & 150.0 & 0.42 & 107.0 & 107.0 & 0.04 & 55.0 & 0.42 & 107.0 & 107.0 & 0.04 \\
\hline Absorptivity $a$ & 0.80 & 0.30 & 0.60 & - & 0.20 & 0.85 & 0.30 & 0.60 & - & 0.20 \\
\hline Emissivity $p$ & 0.35 & - & 0.10 & - & 0.20 & 0.30 & - & 0.10 & - & 0.20 \\
\hline $\begin{array}{l}\text { Thickness } d \\
(\mathrm{~mm})\end{array}$ & 0.30 & 0.40 & 5.00 & 4.00 & 42.50 & 0.70 & 0.40 & 5.00 & 4.00 & 42.50 \\
\hline
\end{tabular}

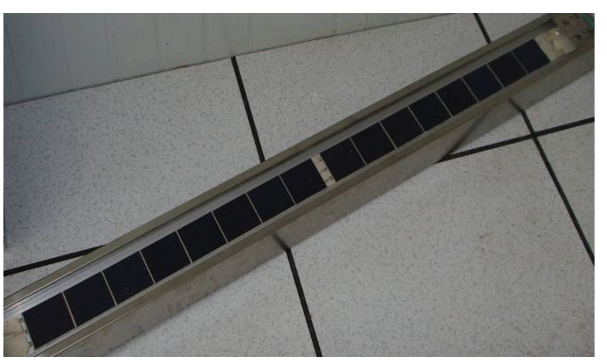

FIGURE 4: The photograph of the super cell array.

Figure 4 is a mono-Si solar cell from the USA, named after the solar cell used for space power. The specification of each cell is $6.2 \mathrm{~cm} \times 7.1 \mathrm{~cm}$. The open-circuit voltage and the short-circuit current of each cell are $0.55 \mathrm{~V}$ and $1.45 \mathrm{~A}$, respectively, with the radiation of $1000 \mathrm{~W} / \mathrm{m}^{2}$ and the cell temperature of $25^{\circ} \mathrm{C}$. The super cell array composed of 16 pieces cell with series connection is tested on the TCPV/T system. The experimental results and simulation results are shown in Figure 5. We can see the simulating curves approximately approach to the experimental testing curves. In concentrating irradiance, the $I-V$ curves approximate linear and the output performances become poor due to its high series resistance.

\subsection{The Electrical Performance of a Triple-Junction GaAs Cell} Array Based on the TCPV/T System. The GaAs cell shown in Figure 6 is a triple-junction solar cell, which is made in Shanghai of China, the specification of each cell is $3.0 \mathrm{~cm}$ $\times 4.0 \mathrm{~cm}$. In nonconcentrating condition, the open-circuit voltage and the short-circuit current of each cell are $2.58 \mathrm{~V}$ and $0.17 \mathrm{~A}$, respectively, with the radiation of $1000 \mathrm{~W} / \mathrm{m}^{2}$ and the cell temperature of $25^{\circ} \mathrm{C}$. The GaAs cell array composed of 40 pieces series-connected cells is tested on the TCPV/T system. According to the experimental testing results, we get the fitted empirical formula of the GaAs solar cell array electrical efficiency which working in concentrating irradiance shown as follows:

$$
\eta_{\mathrm{mp}}=26.06 \%-0.0886 \%\left(T_{p}-T_{\mathrm{ref}}\right) .
$$

4.3. The Electrical Performances and Thermal Performances of the TCPV/T System. The electrical performances and thermal performances of the TCPV/T system with a super cell array and a GaAs cell array are characterized, respectively. All results were achieved with the concentrated irradiance, and the concentration ration was 10.27 . Theoretical calculation results and experimental results are shown in Table 2. The gaps between the theoretical calculation results and experimental results are less than $5 \%$. The model can accurately elucidate the performance characterization of the TCPV/T system. From (13), the maximum efficiency of $26.06 \%$ for the GaAs solar cell array is achieved at the reference temperature of $25^{\circ} \mathrm{C}$. However, the maximum efficiency in our experiments is around 5.8\%. This is because the cell temperature rises significantly with the concentrated irradiance, so the cells are hardly to reach their optimal working temperature.

Although the single-diode equation was applied for the super cell array and the empirical linear equation was applied for the temperature dependence in case of the GaAs module, the electrical efficiencies from the theoretical calculations agree with the measured results well for both cases of cells in Table 2. Comparing with the super cell, the GaAs cell has better high temperature characteristics. In the concentrated irradiance scope of our experiments, the characteristic of the GaAs cell still kept linear, so the empirical linear equation for the GaAs module is appropriate. However, the empirical linear equation for the super cell maybe inappropriate in such concentrated irradiance. The single-diode model could usually improve the model response/accuracy with respect the empirical equation, and the single-diode equation could illustrate the super cell well in our case.

\section{Analysis on Characteristic Parameters of the TCPV/T System with a Super Cell Array and a GaAs Cell Array}

Based on the model, we analyze the influences of the related characteristic parameters on the performance of the TCPV/T system with a super cell array and a GaAs cell array, respectively. The related characteristic parameters include mirror reflectivity, width of focal spot, thermal absorptivity 

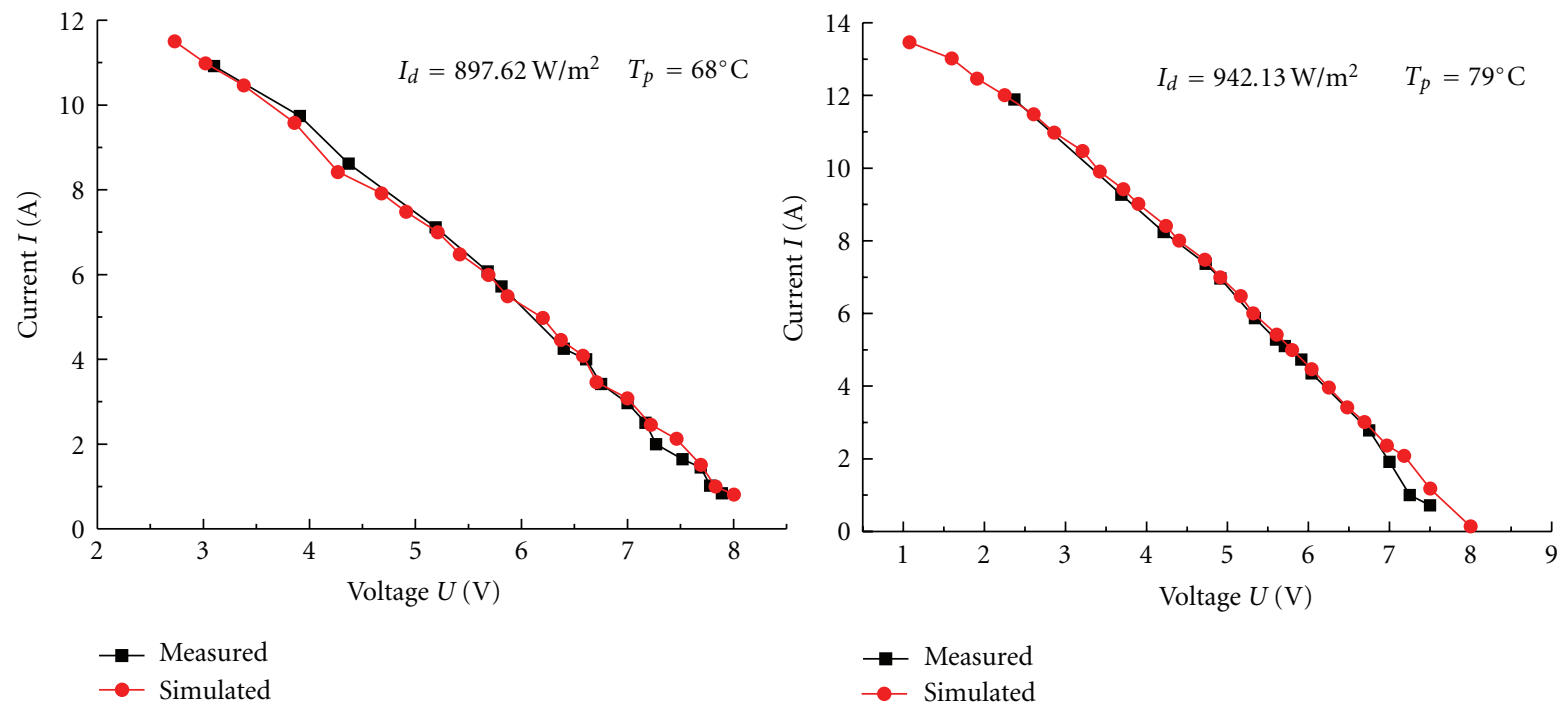

FIGURE 5: The $I-V$ characteristics of the super cell array comparisons between experiments and simulations.

TABLE 2: The theoretical calculation results and the experimental results of the TCPV/T system.

(a)

\begin{tabular}{|c|c|c|c|c|c|c|c|c|c|}
\hline & \multirow{2}{*}{$\begin{array}{c}I_{d}\left(\mathrm{~W} / \mathrm{m}^{2}\right) \\
-\end{array}$} & \multirow{2}{*}{$\begin{array}{c}m(\mathrm{~kg}) \\
-\end{array}$} & \multirow{2}{*}{$\begin{array}{c}T_{\text {in }}\left({ }^{\circ} \mathrm{C}\right) \\
-\end{array}$} & \multirow{2}{*}{$\begin{array}{c}T_{a}\left({ }^{\circ} \mathrm{C}\right) \\
-\end{array}$} & \multirow{2}{*}{$\begin{array}{c}v_{w}\left(\mathrm{~m} / \mathrm{s}^{1}\right) \\
-\end{array}$} & \multicolumn{2}{|c|}{$T_{\text {out }}\left({ }^{\circ} \mathrm{C}\right)$} & \multicolumn{2}{|c|}{$T_{p} /\left({ }^{\circ} \mathrm{C}\right)$} \\
\hline & & & & & & $\mathrm{M}$ & $S$ & $\mathrm{M}$ & $S$ \\
\hline \multirow{2}{*}{ Super cell array } & 905.1 & 0.0050 & 22.6 & 16.7 & 1.7 & 50.1 & 50.5 & 83.2 & 84.40 \\
\hline & 953.7 & 0.0111 & 24.1 & 16.4 & 3.5 & 39.0 & 38.6 & 57.6 & 56.26 \\
\hline \multirow{2}{*}{ GaAs cell array } & 902.1 & 0.008 & 20.1 & 19.9 & 1.0 & 39.1 & 38.6 & 61.4 & 60.20 \\
\hline & 894.2 & 0.008 & 19.8 & 20.2 & 2.0 & 38.2 & 37.8 & 59.4 & 58.3 \\
\hline
\end{tabular}

(b)

\begin{tabular}{lcccccccc}
\hline & \multicolumn{2}{c}{$P_{\max }(\mathrm{W})$} & \multicolumn{2}{c}{$\eta_{t}(\%)$} & & $\eta_{e}(\%)$ & & \multicolumn{1}{c}{$\eta_{0}(\%)$} \\
& $\mathrm{M}$ & $\mathrm{S}$ & $\mathrm{M}$ & $\mathrm{S}$ & $\mathrm{M}$ & $\mathrm{S}$ & $\mathrm{M}$ \\
\hline Super cell array & 34.11 & 33.44 & 32.56 & 33.04 & 1.93 & 1.89 & 34.50 & 34.93 \\
& 41.33 & 42.19 & 37.17 & 36.18 & 2.22 & 2.27 & 39.40 & 38.44 \\
GaAs cell array & 100.80 & 101.94 & 36.12 & 35.17 & 5.73 & 5.80 & 41.85 & 40.96 \\
& 101.92 & 102.71 & 35.29 & 34.52 & 5.85 & 5.89 & 41.13 & 40.41 \\
\hline
\end{tabular}

( $I_{d}$ - direct radiation, $m$-fluid mass, $T_{\mathrm{in}}$-inlet temperature of fluid, $T_{a}$-ambient temperature, $v_{\mathrm{w}}$-wind speed, $T_{\text {out }}$-outlet temperature of fluid, $T_{p}$ temperature of solar cell array, $P_{\max }$ — the maximum power output of system, $\eta_{0}$ — total efficiency; $\mathrm{M}$-measured, $\mathrm{S}$ - simulated).

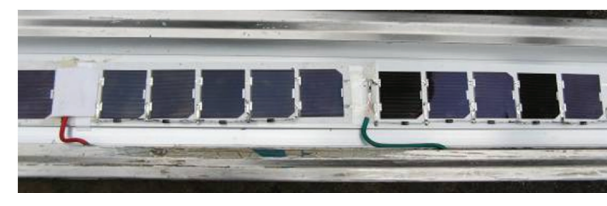

Figure 6: The photograph of the GaAs solar cell array.

of the lighting plate, and solar direct radiation. In order to conveniently calculate and compare, it is supposed that the water mass flow is $0.008 \mathrm{~kg} / \mathrm{s}$, the inlet temperature of fluid is $20.0^{\circ} \mathrm{C}$, solar direct radiation is $900 \mathrm{~W} / \mathrm{m}^{2}$, and the ambient temperature and wind speed are $20.0^{\circ} \mathrm{C}$ and $1.0 \mathrm{~m} / \mathrm{s}$, respectively, in the calculation.
5.1. The Effect of the Mirror Reflectivity. The TCPV/T system reflects and concentrates the solar radiation to the focal spot by using the trough parabolic mirrors. The light intensity can be improved to a high level. It is clearly to see from Figure 7 that with increasing of mirror reflectivity from 0.5 to 0.95 , the electrical efficiency, the thermal efficiency, and the exergy efficiency increase by 0.02 times, 0.94 times, 0.62 times (for the TCPV/T system with a super cell array) and 0.65 times, 0.90 times, 0.93 times (for the TCPV/T system with a GaAs cell array). The electrical efficiency of the super cell array TCPV/T system increases firstly and then drops slightly, that is, due to the concentration ratio of 8.46 is preferred for the optimum output performance of the super cell array (from [16], we can get the conclusion that the parabolic mirror reflectivity of the TCPV/T 


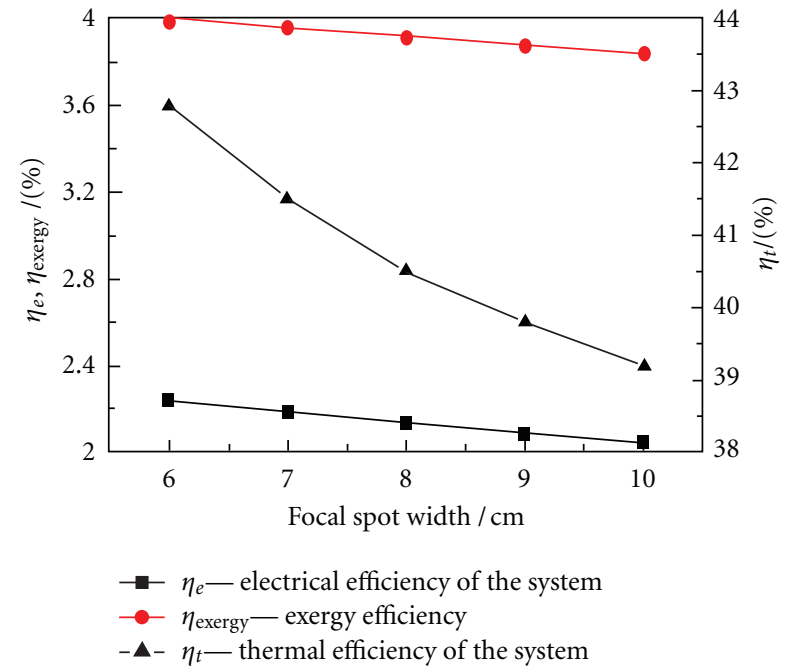

(a) Super cell array TCPV/T system

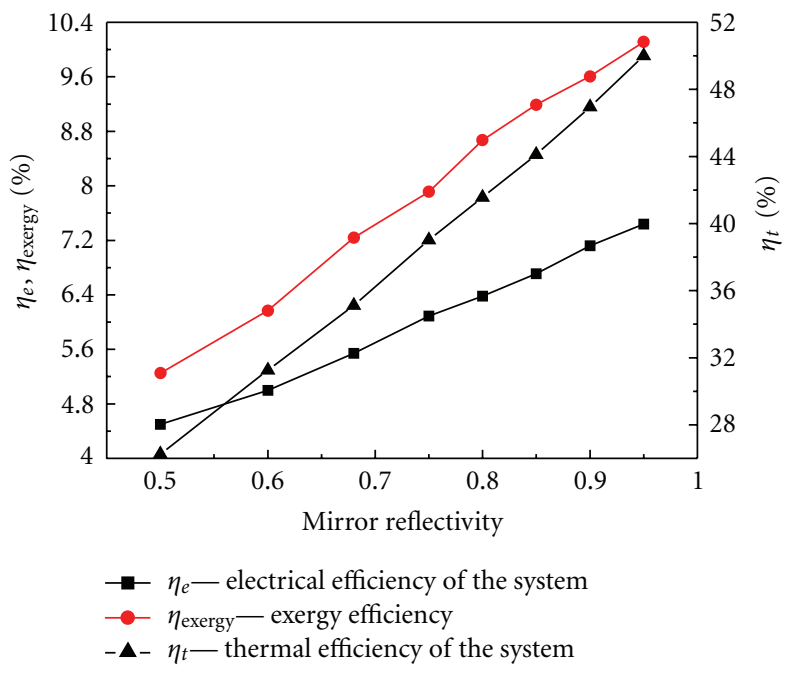

(b) GaAs cell array TCPV/T system

FIgURE 7: The influences of mirror reflectivity on the system performances.

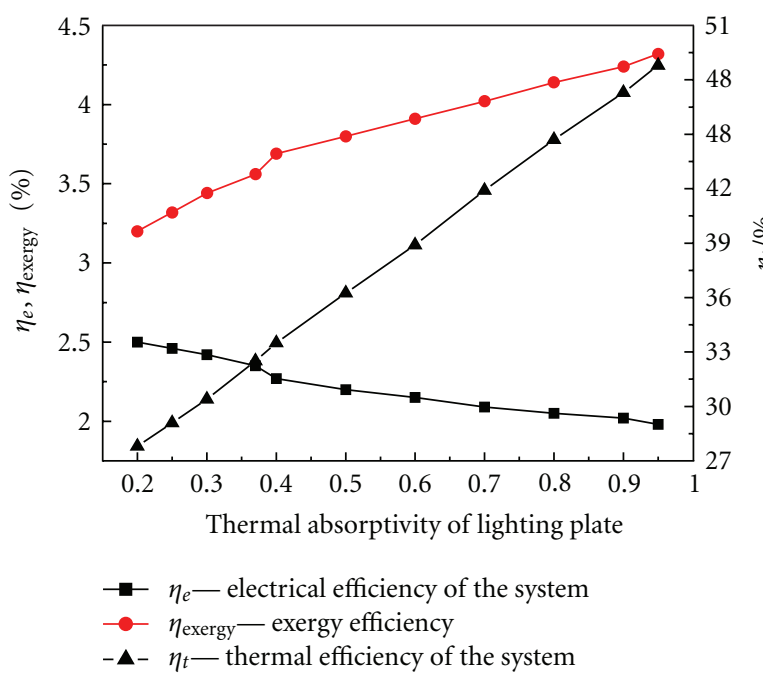

(a) Super cell array TCPV/T system

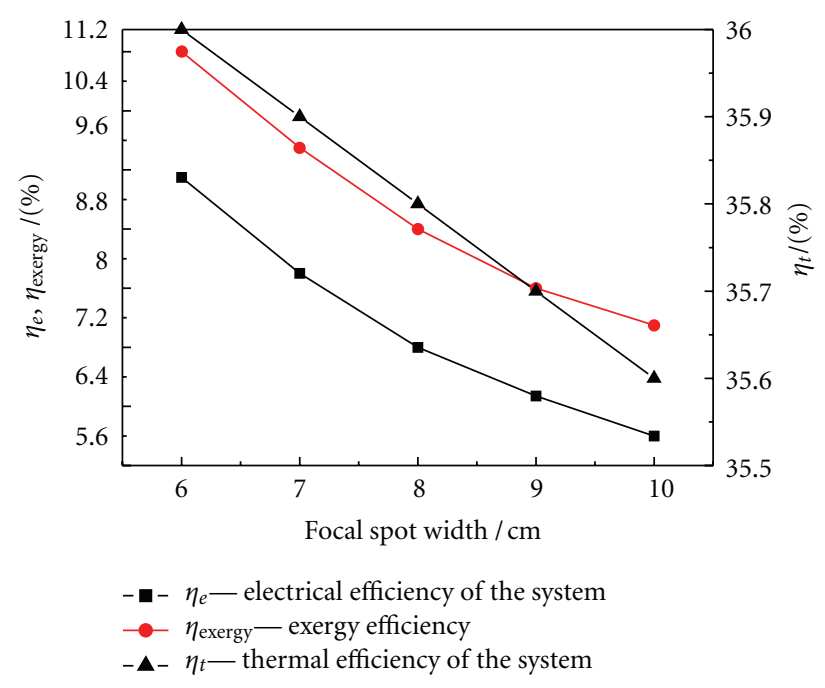

(b) GaAs cell array TCPV/T system

FIGURE 8: The influences of focal spot widths on the system performances.

system is an important factor to determine the utilizing efficiency of solar energy. So it is an effective way to improve the mirror reflectivity for optimizing the TCPV/T system.

5.2. The Effect of the Focal Line Width. The sunlight is concentrated on the focal line which has high-energy flux density. With the same parabolic mirror, the narrower focal line has a higher energy flux density. From Figure 8, we can see the electrical efficiency, the thermal efficiency, and the exergy efficiency all drops with increasing of focal line widths. The widths of the Super cell array and GaAs cell array are $6.2 \mathrm{~cm}$ and $4.0 \mathrm{~cm}$, respectively. When the focal line width is larger than the width of solar cell array, parts of solar energy will be wasted. So a suitable focal line with uniform light intensity distribution indicates a high utilizing efficiency of solar energy.

5.3. The Effect of the Thermal Absorptivity of the Lighting Plate. From Figure 9, although the high thermal absorptivity results in a high-operating temperature of solar cell arrays and a lower electrical efficiency, the thermal efficiency, and exergy efficiency increase by 0.75 times, 0.35 times (for super cell array TCPV/T system) and 1.38 times, 0.14 times (for GaAs cell array TCPV/T system) with the thermal absorptivity of the lighting plate increasing from 0.2 to 0.9 .

5.4. The Effect of Solar Direct Radiations. For the concentrating system, only the solar direct radiation can be utilized, 


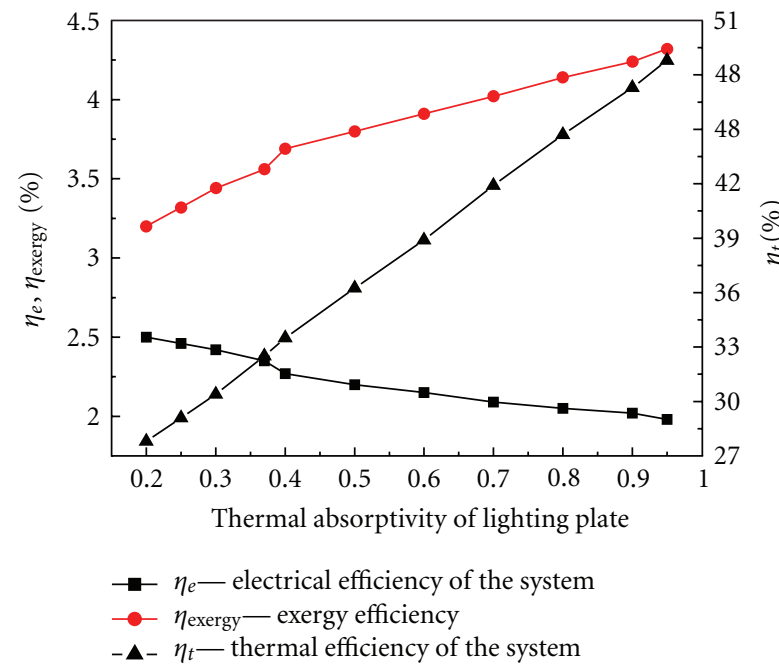

(a) Super cell array TCPV/T system

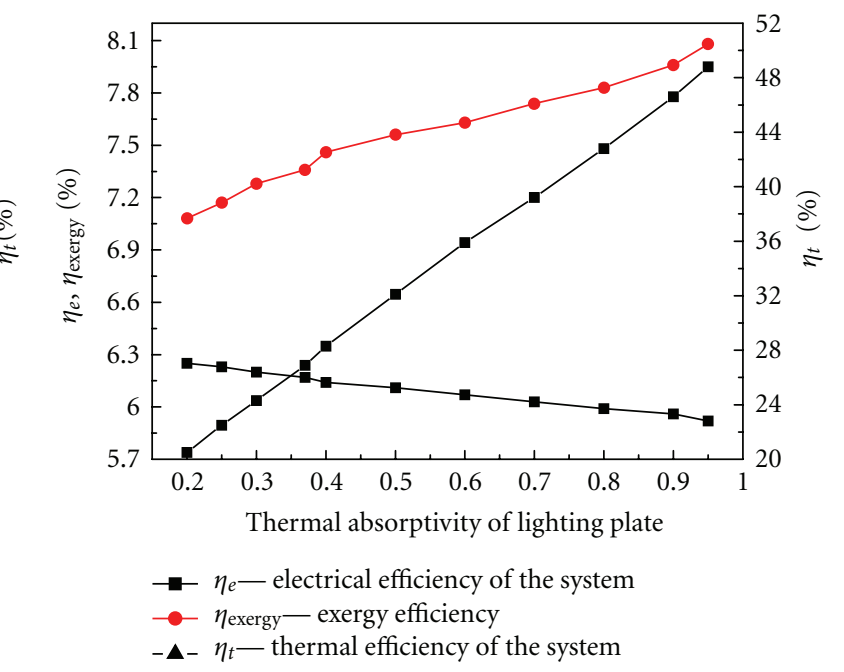

(b) GaAs cell array TCPV/T system

FIGURE 9: The influences of thermal absorptivity of lighting plate on the system performances.

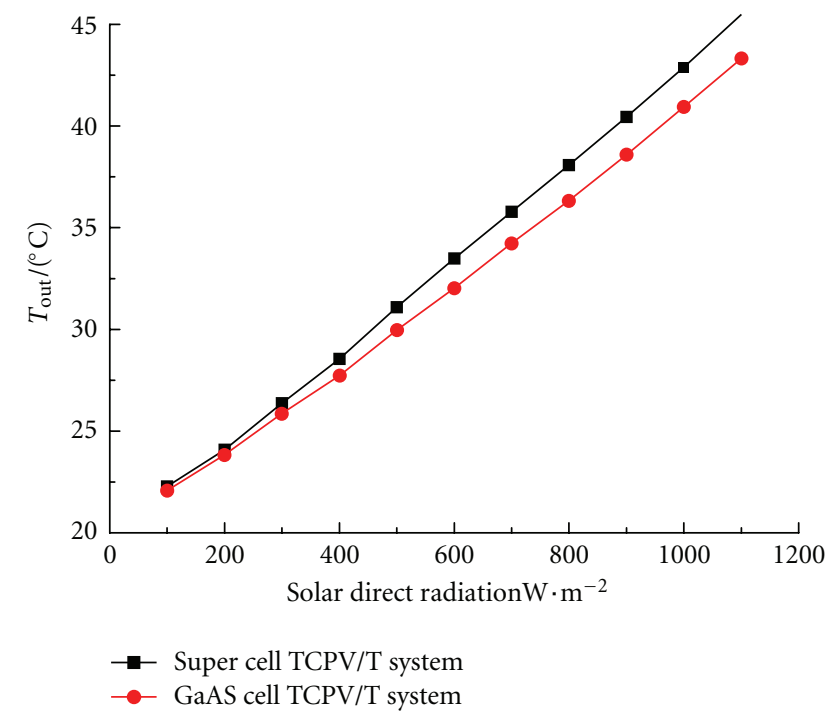

(a)

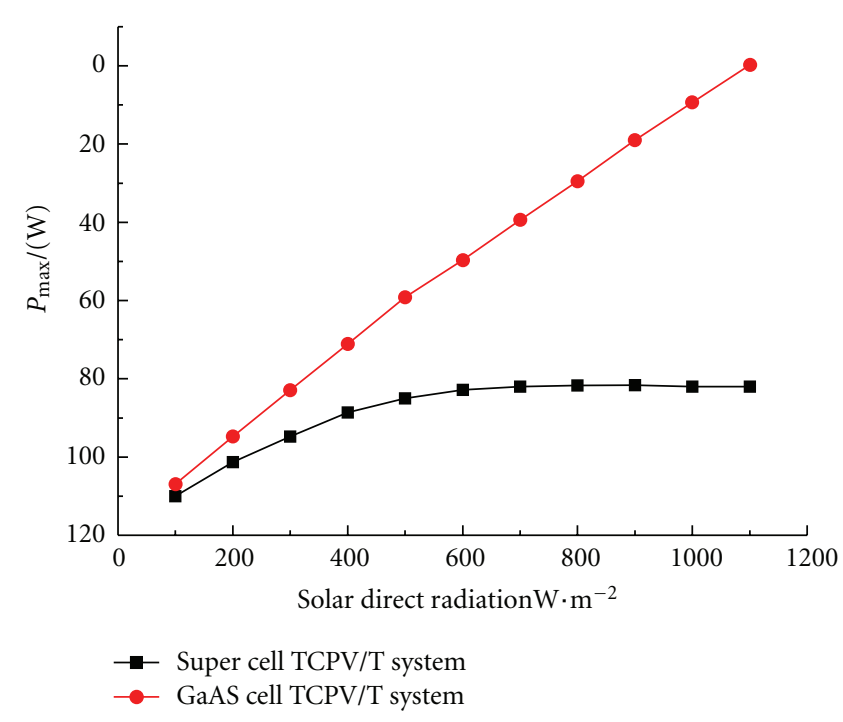

(b)

FIgURE 10: The influences of solar direct radiation on the system performances.

it contributes to the input energy, directly influences the maximum electrical power output of solar cell array and outlet temperature of fluid directly, so the effect of solar direct radiation to the performances of TCPV/T system should be discussed.

Figure 10 shows that the outlet fluid temperatures of the $\mathrm{TCPV} / \mathrm{T}$ systems with super cell array and GaAs cell array increase linearly with the rising of solar direct radiation. With the rising of solar direct radiation, the maximum electrical power output of the GaAs cell array TCPV/T system increases linearly, but that of the super cell array TCPV/T system increases firstly and then tends to be steady. We can see from Figure 10 that the optimum solar direct radiation for the super cell array TCPV/T system is $700 \mathrm{~W} / \mathrm{m}^{2}$.

\section{Conclusions}

(1) The energy flow balance equations of the CPV/T system are deduced, and the one-dimension steady models of a trough concentrating photovoltaic/thermal system with a Super cell array and a GaAs cell array are established, respectively.

(2) In our validation experiments using a $2 \mathrm{~m}^{2} \mathrm{TCPV} / \mathrm{T}$ system, the gaps between the theoretical calculation results based on the above models and the experimental results are less than $5 \%$, which indicate that the models are valid.

(3) Based on the model, we analyze the influences of the related characteristic parameters such as mirror 
reflectivity, width of focal spot, thermal absorptivity of the lighting plate, and solar direct radiation on the performances of the TCPV/T system with a super cell array and a GaAs cell array, respectively. The parabolic mirror reflectivity of the TCPV/T system is an important factor to determine the utilizing efficiency of solar energy. We can optimize the TCPV/T system by improving the mirror reflectivity and thermal absorptivity of the lighting plate, pursuing a suitable focal line with uniform light intensity distribution.

\section{Nomenclature}

A : Quality factor of the diode

$A_{m}: \quad$ Effective area of the reflecting mirror $\left(\mathrm{m}^{2}\right)$

$A_{t}$ : Internal surface area of the conduit $\left(\mathrm{m}^{2}\right)$

$c_{p, f}: \quad$ Specific heat capacity $\left(\mathrm{kJ} /\left(\mathrm{kg} \cdot{ }^{\circ} \mathrm{C}\right)\right)$

$h: \quad$ The specific enthalpy $(\mathrm{kJ} / \mathrm{kg})$

$h_{t-f}$ : Convective heat transfer coefficient between the conduit and the fluid $\left(\mathrm{W} /\left(\mathrm{m}^{2 \circ} \mathrm{C}^{1}\right)\right)$

I: $\quad$ Current $(A)$

$I_{0}$ : $\quad$ Reverse saturation current of the diode $(A)$

$I_{d}: \quad$ Solar direct radiation $\left(\mathrm{W} / \mathrm{m}^{2}\right)$

$I_{L}$ : Photocurrent $(A)$

$k$ : $\quad$ Boltzmann' constant

$m: \quad$ Fluid mass $(\mathrm{kg})$

$n: \quad$ Pieces of solar cell

$\eta_{\mathrm{mp}}$ : $\quad$ Electrical efficiency of solar cell array (\%)

$\eta_{\text {mp,ref }}:$ Reference efficiency (\%)

$\eta_{t}: \quad$ Thermal efficiency of system (\%)

$\eta_{e}: \quad$ Electrical efficiency of system (\%)

$\eta_{\text {exergy: }}$ Exergy efficiency (\%)

$P_{\max }$ : Maximum electrical power output (W)

$q: \quad$ Elementary charge (C)

$Q_{P}$ : $\quad$ Solar direct radiant energy on the solar cell array $(\mathrm{kJ})$

$Q_{P 1}$ : Concentrating solar direct radiant energy on the aluminum alloy plate $(\mathrm{kJ})$

$R_{s}: \quad$ Series resistance $(\Omega)$

$R_{\text {cpa }}$ : Convective heat transfer thermal resistances between solar cell array and the surroundings $(\Omega)$

$R_{\text {rpa }}$ : Radiative heat transfer thermal resistances between solar cell array and the surroundings $(\Omega)$

$R_{\mathrm{kpB}}$ : Heat-conductive thermal resistance between solar cell array and the thermally conductive tape $(\Omega)$

$R_{\mathrm{kBpl}}$ : Heat-conductive thermal resistance between the thermally conductive tape and the aluminum alloy plate $(\Omega)$

$R_{\text {kplc }}$ : Heat-conductive thermal resistance between aluminum alloy plate and the thermally insulating layer $(\Omega)$

$R_{\text {kplt }}$ : Heat-conductive thermal resistance between aluminum alloy plate and the conduit $(\Omega)$

$R_{\text {rpla }}$ : Convective heat transfer thermal resistances between the aluminum alloy plate and the surroundings $(\Omega)$

$R_{\text {cpla }}$ : Radiative heat transfer thermal resistances between the aluminum alloy plate and the surroundings $(\Omega)$
$R_{\text {rca }}$ : Radiative heat transfer thermal resistance between the thermally insulating layer and the surroundings $(\Omega)$

$R_{\text {cca }}$ : Convective heat transfer thermal resistance between the thermally insulating layer and the surroundings $(\Omega)$

$s: \quad$ The specific entropy $\left(\mathrm{kJ} /\left(\mathrm{kg} \cdot{ }^{\circ} \mathrm{C}\right)\right)$

$t$ : Operating time $(s)$

$T_{a}: \quad$ Ambient temperature $\left({ }^{\circ} \mathrm{C}\right)$

$T_{B}$ : Temperature of the thermally conductive tape $\left({ }^{\circ} \mathrm{C}\right)$

$T_{\text {cover }}$ : Average temperature of the thermally insulating layer $\left({ }^{\circ} \mathrm{C}\right)$

$T_{p}$ : Working temperature of solar cell array $\left({ }^{\circ} \mathrm{C}\right)$

$T_{\text {plate: }}$ Temperature of the aluminum alloy plate $\left({ }^{\circ} \mathrm{C}\right)$

$T_{t}$ : $\quad$ Temperature of the conduit $\left({ }^{\circ} \mathrm{C}\right)$

$T_{\text {out }}$ : Outlet temperature of fluid $\left({ }^{\circ} \mathrm{C}\right)$

$T_{\text {in }}$ : Inlet temperature of fluid $\left({ }^{\circ} \mathrm{C}\right)$

$T_{\text {ref: }}$ The reference temperature $\left({ }^{\circ} \mathrm{C}\right)$

$\mu_{p, \mathrm{mp}}$ : Related coefficient between the electrical efficiency of the solar cell array and the temperature $\left(\% /{ }^{\circ} \mathrm{C}\right)$

$V: \quad$ Load voltage $(V)$.

\section{Acknowledgments}

The present study was supported by National Natural Science Foundation, China (Grant nos. 50966004, 51106134, and U1137605), the program of Changjiang Scholars and Innovative Research Team in Ministry of Education, China.

\section{References}

[1] J. S. Coventry, "Performance of a concentrating photovoltaic/thermal solar collector," Solar Energy, vol. 78, no. 2, pp. 211-222, 2005.

[2] J. S. Coventry and K. Lovegrove, "Development of an approach to compare the 'value' of electrical and thermal output from a domestic PV/thermal system," Solar Energy, vol. 75, no. 1, pp. 63-72, 2003.

[3] J. Conventry, E. Franklin, and A. Blakers, "Thermal and electrical performance of a concentrating PV/Thermal collector: results from the ANU CHAPS collector," in Proceedings of the 40th Conference of the Australia and New Zealand Solar Energy Society (ANZSES '02), Newcastle, Australia, 2002.

[4] G. Mittelman, A. Kribus, and A. Dayan, "Solar cooling with concentrating photovoltaic/thermal (CPVT) systems," Energy Conversion and Management, vol. 48, no. 9, pp. 2481-2490, 2007.

[5] A. Kribus, D. Kaftori, G. Mittelman, A. Hirshfeld, Y. Flitsanov, and A. Dayan, "A miniature concentrating photovoltaic and thermal system," Energy Conversion and Management, vol. 47, no. 20, pp. 3582-3590, 2006.

[6] S. K. Tyagi, S. W. Wang, M. K. Singhal, S. C. Kaushik, and S. R. Park, "Exergy analysis and parametric study of concentrating type solar collectors," International Journal of Thermal Sciences, vol. 46, no. 12, pp. 1304-1310, 2007.

[7] H. Zhai, Y. J. Dai, and J. Y. Wu, "Investigation of concentrating solar photovoltaic/thermal system performance based on Fresnel lens," Journal of Engineering Thermophysics, vol. 28, no. 5, pp. 725-728, 2007.

[8] J. Sun and M. H. Shi, "Energy and exergy efficiency analysis of a solar concentrating PV/T air heating collector," Journal 
of Engineering Thermophysics, vol. 30, no. 11, pp. 1929-1932, 2009.

[9] M. Li, G. L. Li, X. Ji, F. Yin, and L. Xu, "The performance analysis of the Trough Concentrating Solar Photovoltaic/Thermal system," Energy Conversion and Management, vol. 52, no. 6, pp. 2378-2383, 2011.

[10] L. Ming, J. Xu, L. Guo-liang et al., "Performance investigation and optimization of the Trough Concentrating Photovoltaic/Thermal system," Solar Energy, vol. 85, no. 5, pp. 10281034, 2011.

[11] M. Xiang, M. Li, L. L. Wang et al., "Investigation of performance on Trough Concentrating Solar Photovoltaic/Thermal System based on super cells," Acta Optica Sinica, vol. 29, no. 2, pp. 482-489, 2009.

[12] Y. F. Wang, M. Li, W. X. Lin et al., "Performance analysis on solar cell modules of flat-plate and Trough Concentrating Photovoltaic System," Acta Optica Sinica, vol. 29, no. 8, pp. 2287-2292, 2009.

[13] J. Ji, J. P. Lu, T. T. Chow, W. He, and G. Pei, "A sensitivity study of a hybrid photovoltaic/thermal water-heating system with natural circulation," Applied Energy, vol. 84, no. 2, pp. 222-237, 2007.

[14] T. Bergene and O. M. Løvvik, "Model calculations on a flatplate solar heat collector with integrated solar cells," Solar Energy, vol. 55, no. 6, pp. 453-462, 1995.

[15] B. J. Huang, W. C. Hung, and F. S. Sun, "Performance evaluation of solar photovoltaic/thermal systems," Solar Energy, vol. 70, no. 5, pp. 443-448, 2001.

[16] Y. F. Xu, M. Li, L. L. Wang et al., "The effect of concentrated light intensity on output performance of solar cell arrays," Acta Physica Sinica, vol. 58, no. 11, pp. 8067-8076, 2009. 


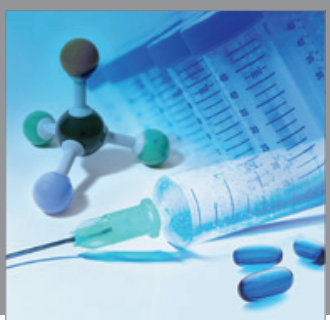

International Journal of

Medicinal Chemistry

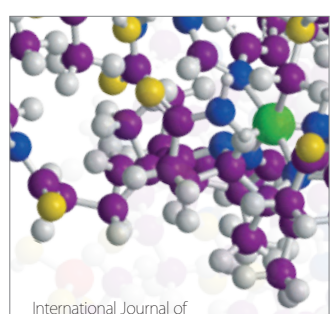

Carbohydrate Chemistry

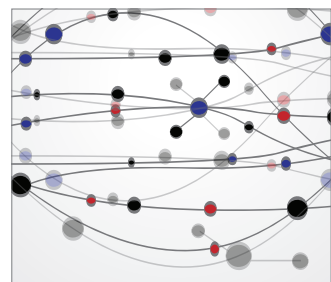

The Scientific World Journal
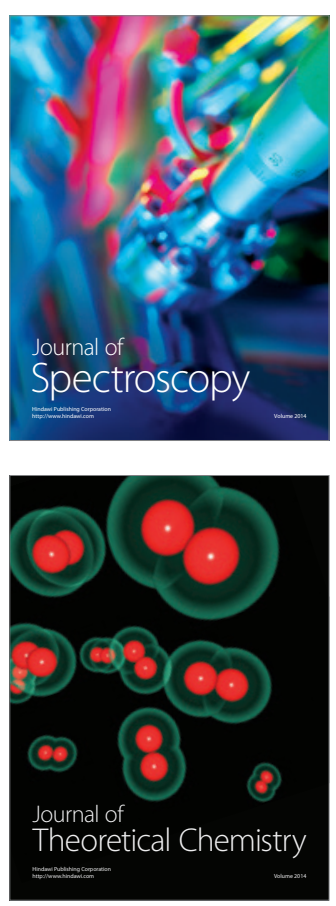
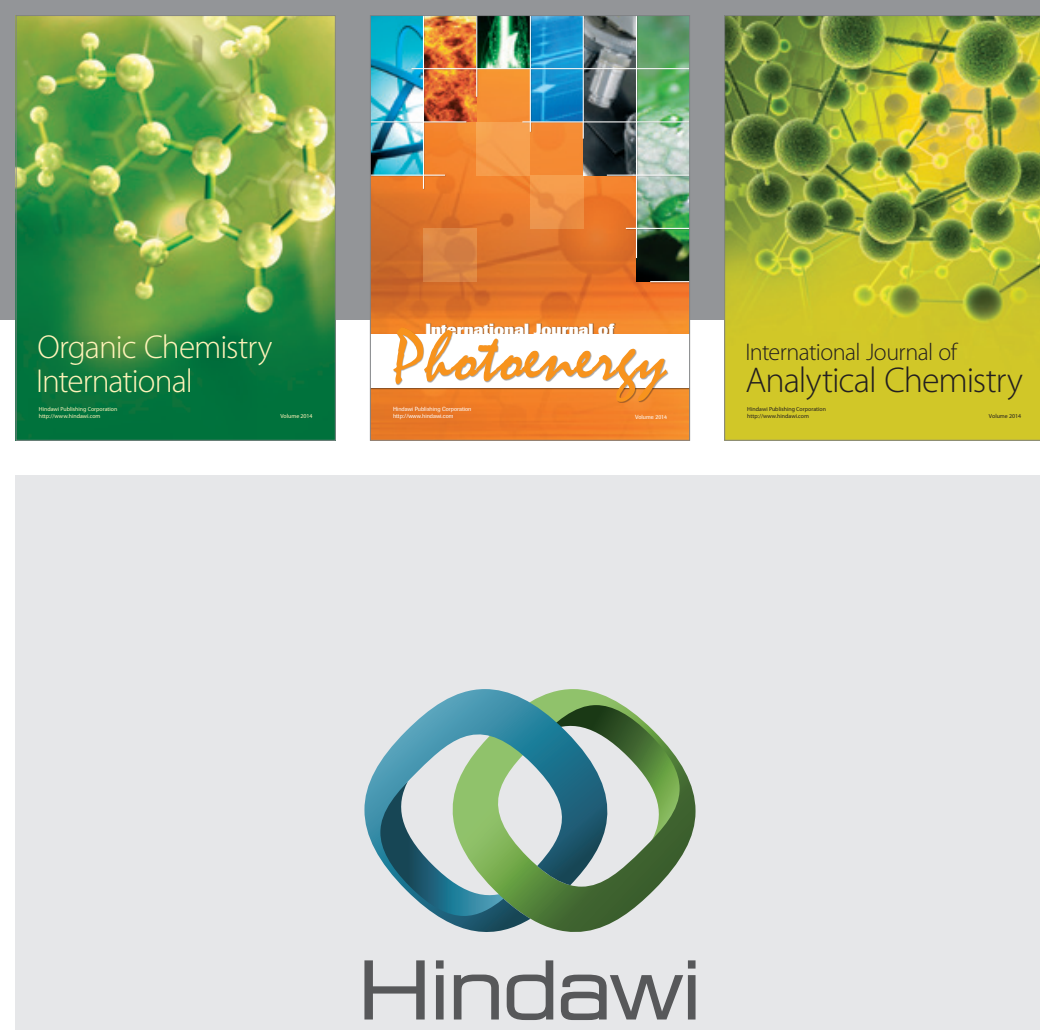

Submit your manuscripts at

http://www.hindawi.com
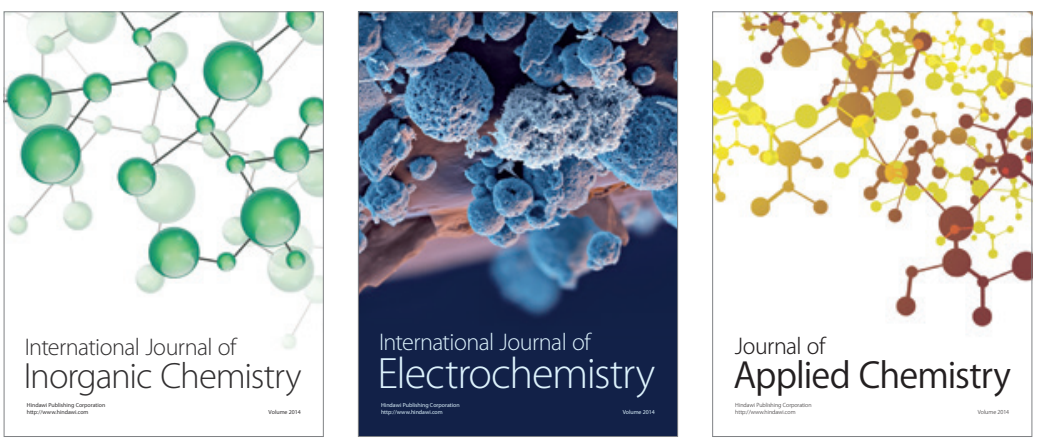

Journal of

Applied Chemistry
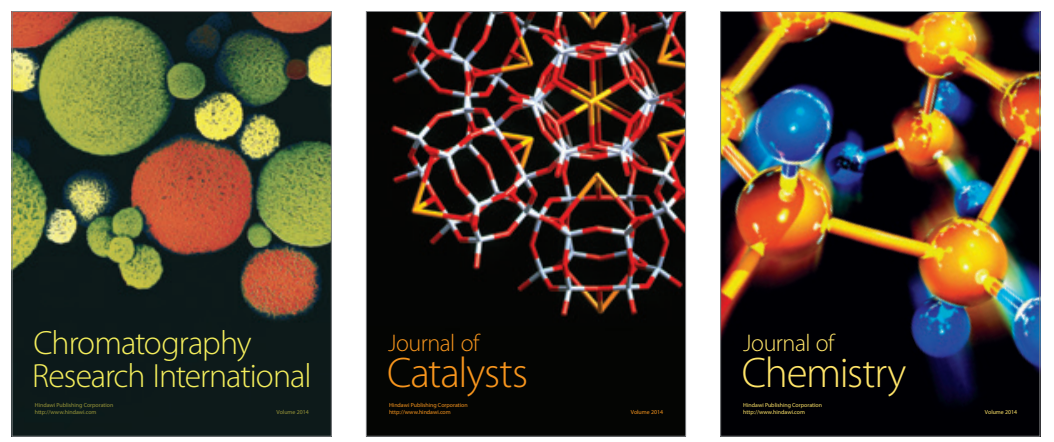
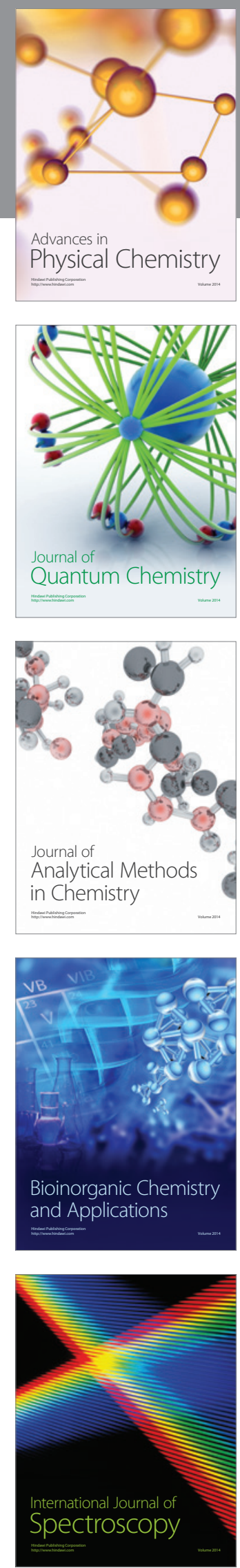